\section{Journal of Sciences and \\ Engineering}

Vol. 5, $\mathrm{N}^{\circ}$ 2, 2021

\title{
Didactic and technological tool to encourage study in students of the Systems Engineering School at the National University of Trujillo [Herramienta didáctica y tecnológica para incentivar el estudio en los alumnos de la Escuela de Ingeniería de Sistemas de la Universidad Nacional de Trujillo]
}

\author{
Luis E. Boy (iD a *, Juan C. Obando a \\ a Facultad de Ingeniería, Universidad Nacional de Trujillo. Av. Juan Pablo II s/n - Ciudad Universitaria, \\ Trujillo, Perú \\ *lboy@unitru.edu.pe
}

Received: 20 October 2021; Accepted: 02 November 2021; Published: 09 November 2021

\begin{abstract}
Resumen
La presente investigación tiene como objetivo analizar y evaluar una herramienta didáctica y tecnológica y ver el impacto para incentivar el estudio en los estudiantes de la Escuela de Ingeniería de Sistemas de la Universidad Nacional de Trujillo, durante el semestre 2020-II. Se logró implementar la aplicación Stormboard para el desarrollo de Brainstorming como una estrategia didáctica a través de la cual se pretende incentivar el aspecto creativo e innovador de los estudiantes a la hora de abordar temas y casos de estudio. Analizando los resultados obtenidos, podemos señalar que se determinaron impactos en el nivel de motivación para el estudio de los estudiantes con un valor del 8\%, así como el impacto en el nivel de percepción de los servicios educativos de los estudiantes se determinó en el orden del $24 \%$ y finalmente, se obtuvieron resultados del impacto en el nivel de satisfacción de los estudiantes del orden del $17 \%$. Finalmente, se propone que estas iniciativas didácticas sean tomadas en cuenta en las políticas académicas e institucionales de la Facultad de Ingeniería de Sistemas con el fin de extrapolar la práctica a otras unidades académicas de la Universidad Nacional de Trujillo.
\end{abstract}

Palabras clave: Didáctica, Tecnología, Comunidad Virtual.

\begin{abstract}
The present research aims to analyze and evaluate a didactic and technological tool and see the impact to encourage study in the students of the Systems Engineering School at the National University of Trujillo, during the 2020-II semester. It was possible to implement the Stormboard application for the development of Brainstorming as a didactic strategy through which it is intended to encourage the creative and innovative aspect of students when addressing topics and case studies. Analyzing the results obtained, we can point out that impacts were determined on the level of motivation for the study of students with a value of $8 \%$, as well as the impact on the level of perception of educational services of students was determined in the order of $24 \%$ and finally, results of the impact on the level of student satisfaction were obtained in the order of $17 \%$. Finally, it is proposed that these didactic initiatives be taken into account in the academic and institutional policies of the Systems Engineering School of in order to extrapolate the practice to other academic units at the National University of Trujillo.
\end{abstract}

Keywords: Didactics, Technology, Virtual Community. 


\section{SE \\ Journal of Sciences and Engineering}

Vol. 5, $\mathrm{N}^{\circ} 2,2021$

Copyright @ 2021, CINCADER.

ISSN 2523-9503

DOI: https://doi.org/10.32829/sej.v5i2.143

\section{Introduction}

Humanity has always set itself challenges for its progress, the main purpose of which is to satisfy its demands aimed at achieving an improvement in its quality of life; Hence, technological evolution plays a fundamental role since the result of technological processes are concrete objects transformed into goods or services oriented to society. Technology is applied today in all fields of human activity, especially in the field of education, promoting the development of various tools to facilitate teaching and learning processes, therefore, referring to the research of (Rodriguez, 2016); who concludes that the use of the "Chamilo" platform in the teaching-learning process of the English language is perceived positively since it facilitates the document management of the course, as well as the development of online exercises and virtual tasks. Similarly, the authors (Gonzales \& Moreno, 2018) conclude that extrinsic motivational orientation is predominant with respect to the student's self-stimuli; Likewise (Camilo \& Marín, 2014) found that the identification and registration of good practices allow new university projects to have greater relevance, and the increased interest in the use of this tool improved through mobile devices. The research carried out by (Fierro Barriales, 2018) found that the B-learning model produced a $60 \%$ increase in the learning of high school students; thus, it is also necessary to point out the work carried out by (More \& Velasco, 2018) who developed a Virtual Tutor, having found that motivation and empathy are determining strengths of said Virtual Tutor. Technology is also manifested in the field of industry, providing support through various machines and machinery to make productive work easier and more profitable. Currently, there are technological tools to facilitate collaborative learning in which students develop projects or tasks in work groups, there are also technological tools to support learning by competencies, providing facilities for accessing information from anywhere in the world.

Despite the fact that, unfortunately, nowadays an immense amount of information circulates through the network producing an informational pollution, which means that not all the contents are really useful for the different purposes of the learner, despite this, the new challenge of teaching is to ensure that the student can be able to search for relevant information at all times, select it, process it, interpret it and apprehend it to generate the required knowledge. There are also technological tools that promote learning through playful processes that allow students to participate in their learning process with the use of educational games. The tools also provide all kinds of facilities for a virtual education with the use of communications technology; Thus, the teacher can develop their classes online, that is, with a synchronous connection with the student, or they can also develop it with asynchronous connections, so that students can access these classes when they require it.

\section{Methodology}

The population in this study is made up of 243 students from the Systems Engineering School at the National University of Trujillo with current enrollment during the 2020-II semester. This research is applied, since according to the aim pursued, it is based on existing knowledge and in terms of design, the research is descriptive, because reality is not manipulated. For hypothesis testing, the pre-test, post-test method was used with two intact groups whose subsamples were of size $\mathrm{ni}=28$ students in each subgroup; and the t-student distribution test was applied since the value $n$ is less than 30 . Next, a measurement of the dependent variable was made to the control subgroup, in the instants before the application of the stimulus; then the stimulus was applied to the research subgroup and a measurement of the dependent variable was made, in the moments after the application of the stimulus. Graphically, the design is as follows: 
Vol. 5, $\mathbf{N}^{\circ}$ 2, 2021

\section{SE \\ Journal of Sciences and Engineering}

Copyright (C) 2021, CINCADER.

ISSN 2523-9503

DOI: https://doi.org/10.32829/sej.v5i2.143

Gt:

Gi:

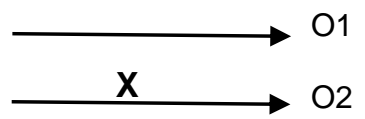

Where:

Gi: Research group

Gt: Control group

01: Pre-test observations to the control group

O2: Post-Test Observations to the research group

$\mathrm{X}$ : Teaching and technological tool (Independent variable)

The didactic and technological tool that is identified and used in this study is called the didactic technique of Brainstorming, which is also known as the brainstorming technique, or brainstorming; This technique promotes teamwork and encourages collaborative work by fostering the creativity of team members. The term Brainstorming was used for the first time in 1941 by the American publicist Alex Orborn, perhaps taking as a reference the Mayneutic technique revealed by the Greek philosopher Socrates, who proposed the dialogue with his students to arrive at the truth, this method began with questions about the issues he posed to the discussion, and then critically confronted and analyzed the answers, until they all came up with an answer that seemed true to them. Precisely, the brainstorming technique consists of generating new ideas and a set of answers of all sense to a specific topic, until reaching a consensus about the solution to the problem posed. Among the main advantages of Brainstorming as a didactic tool in an educational process, we have to facilitate interpersonal relationships between team members, promote the creativity of the participants by improving their performance and promoting consensus solutions to the topic under discussion. Among the tools that are usually used in a Brainstorming session we have Mind Maps, where concepts related to a main topic are elaborated, we also have the Letter Map which is similar to the mind map, but here, the new ideas are concentrated in words of each level of detail of the concepts. Another tool is the SWOT analysis where the strengths, weaknesses, opportunities and threats of the related topic are analyzed. We also have the Basic questions raised to deepen the analysis of a topic, another tool is the notebook of ideas where a log of previous agreements is elaborated to facilitate the new agreements. Thus, there is also the electronic whiteboard that consists of the use of large spaces for the content of the advances, adhesive notes are also used that can be easily exchanged when required; Another tool can be an electronic medium such as sound or video recorders, pencils of various colors; etc.

The development of this research was carried out through the following steps:

a) In order to carry out the research, we proceeded to form two subgroups of students from the sample, randomly and without any privilege among the students.

b) The first group is called Control group; made up of students to whom the didactic and technological tool was not applied, during the 2020-II semester.

c) The second group is called Research Group; made up of students to whom, if the didactic and technological tool was applied, during the 2020 -II semester.

d) To obtain the measurements of the study variables, a survey was applied at the pre-test and post-test instants respectively.

e) For the qualitative indicator "level of motivation for the study"; The survey contains 04 questions, of which the first two refer to intrinsic motivations, and the other two questions to extrinsic motivations for the study by the students.

f) For the qualitative indicator "level of perception of educational services"; this same survey contains 02 questions.

g) For the qualitative indicator "level of student satisfaction", the same survey contains 02 questions. 


\section{Journal of Sciences and Engineering}

Vol. 5, $\mathrm{N}^{\circ} 2,2021$

Copyright (C) 2021, CINCADER.

ISSN 2523-9503

DOI: https://doi.org/10.32829/sej.v5i2.143
A publication of

\section{CINCADER}

Centre of Research and Training for

Regional Development

Online at www.journals.cincader.org

\section{Results}

Taking into account that the hypothesis was raised: A didactic and technological tool favorably encourages study in students of the Systems Engineering School at the National University of Trujillo, during the 2020-II semester; For this, data were collected through surveys; With closed questions, for the evaluation of the indicators: I1: Level of motivation for the study; containing questions for the analysis of intrinsic and extrinsic motivations, 12: Level of perception of educational services; explored from the point of view of the students; and I3: Level of student satisfaction. The questionnaire was applied to each subgroup of students, in two moments: before (pre-test) and after (post-test). Likewise, the following Likert of 5 alternatives was used for the answers to the questionnaire.

Table 1. Likert responses to the questionnaire

\begin{tabular}{clc}
\hline Alternative & \multicolumn{1}{c}{ Detail } & Nominal value \\
\hline A & Very satisfied & 5 \\
B & satisfied & 4 \\
\hline C & Neither satisfied nor dissatisfied & 3 \\
\hline D & Dissatisfied & 2 \\
\hline E & Very unsatisfied & 1
\end{tabular}

The statistical test for qualitative indicator "Level of motivation for the study".

Table 2. Results for the motivation level for the study

\begin{tabular}{llcccc}
\hline & & \multicolumn{2}{c}{ Pre test } & \multicolumn{2}{c}{ Post test } \\
\hline \multirow{2}{*}{$\begin{array}{l}\text { Motivation } \\
\text { for the study }\end{array}$} & $\Sigma$ & Xa & $\Sigma$ & Xd \\
\cline { 2 - 5 } & Extrinsic & 75 & 2.6786 & 90 & 3.2143 \\
\cline { 2 - 5 } & & 85 & 3.0357 & 99 & 3.5357 \\
\cline { 2 - 5 } & 92 & 3.2857 & 93 & 3.3214 \\
\hline
\end{tabular}

Definition of variables

$\mu A$ : Level of motivation for the study of the Systems Engineering students at the National University of Trujillo before the application of didactic and technological tools.

$\mu \mathrm{B}$ : Level of motivation for the study of the Systems Engineering students at the National University of Trujillo after the application of didactic and technological tools.

Null Hypothesis ( $\mathrm{HO})$ : A didactic and technological tool, it has no effect on the Level of motivation for the study of the Systems Engineering students at the National University of Trujillo, in the 2020-II semester. $\mathrm{HO}: \mu \mathrm{B}-\mu \mathrm{A} \leq 0$

Alternative Hypothesis (Ha): A didactic and technological tool, increases the Level of motivation for the study of the Systems Engineering students at the National University of Trujillo, in the 2020-II semester. Ha: $\mu \mathrm{B}-\mu \mathrm{A}>0$

Result of the statistical hypothesis test

$\mathrm{t} \alpha=0.05=3.18$

tc $=-3.92249024$ 


\section{Journal of Sciences and Engineering}

Vol. 5, $\mathrm{N}^{\circ} 2,2021$

Given that: 3.18> -3.92249 ; the null hypothesis $\mathrm{H} 0$ must be rejected: $\mu \mathrm{B}-\mu \mathrm{A} \leq 0$; and therefore, the alternative hypothesis Ha must be accepted: $\mu \mathrm{B}-\mu \mathrm{A}>0$.

It is concluded then that a didactic and technological tool to encourage study increases the level of motivation for study in Systems Engineering students at the National University of Trujillo, in the 2020-II semester.

Statistical test for qualitative indicator "Level of perception of educational services"

Table 3. Results for the perception level of educational services

\begin{tabular}{lcccc}
\hline & \multicolumn{2}{c}{ Pre test } & \multicolumn{2}{c}{ Post test } \\
\hline & $\Sigma$ & Xa & $\Sigma$ & Xd \\
\hline Perception level of & 72 & 2.5714 & 90 & 3.2143 \\
\cline { 2 - 5 } educational services & 75 & 2.6786 & 93 & 3.3214 \\
\hline
\end{tabular}

Definition of variables

$\mu \mathrm{A}$ : Level of perception of educational services by Systems Engineering students at the National University of Trujillo before the application of didactic and technological tools.

$\mu \mathrm{B}$ : Level of perception of educational services by Systems Engineering students at the National University of Trujillo after the application of didactic and technological tools.

Null Hypothesis (H0): A didactic and technological tool, it has no effect on the level of perception of educational services by Systems Engineering students at the National University of Trujillo, in the 2020-II semester. $\mathrm{H} 0: \mu \mathrm{B}-\mu \mathrm{A} \leq 0$

Alternative Hypothesis (Ha): A didactic and technological tool increases the level of perception of educational services by Systems Engineering students at the National University of Trujillo, in the 2020-II semester. Ha: $\mu \mathrm{B}-\mu \mathrm{A}>0$

Result of the statistical hypothesis test

$\mathrm{ta}=0.05=12.71$

tc $=-1.0833 \mathrm{E}+16$

Given that: $12.71>-1.0833 \mathrm{E}+16$; the null hypothesis $\mathrm{H} 0$ must be rejected: $\mu \mathrm{B}-\mu \mathrm{A} \leq 0$; and therefore, the alternative hypothesis Ha must be accepted: $\mu \mathrm{B}-\mu \mathrm{A}>0$.

It is concluded then that a didactic and technological tool increases the level of perception of educational services by Systems Engineering students at the National University of Trujillo, in the 2020-II semester.

Statistical test for qualitative indicator "Level of student satisfaction"

Table 4. Results for the level of student satisfaction

\begin{tabular}{lcccc}
\hline & \multicolumn{2}{c}{ Pre test } & \multicolumn{2}{c}{ Post test } \\
\hline \multirow{2}{*}{$\begin{array}{l}\text { Level of student } \\
\text { satisfaction }\end{array}$} & 76 & Xa & \multicolumn{2}{c}{ Xd } \\
\cline { 2 - 5 } & 81 & 2.7143 & 88 & 3.1429 \\
\hline
\end{tabular}




\section{Journal of Sciences and \\ Engineering}

Vol. 5, $\mathrm{N}^{\circ} 2,2021$

Copyright (c) 2021, CINCADER.

ISSN 2523-9503

DOI: https://doi.org/10.32829/sej.v5i2.143

\section{CINCADER}

Centre of Research and Training for

Regional Development Online at www.journals.cincader.org

Definition of variables

$\mu \mathrm{A}$ : Level of satisfaction of the Systems Engineering students at the National University of Trujillo before the application of the didactic and technological tool.

$\mu \mathrm{B}$ : Level of satisfaction of the Systems Engineering students at the National University of Trujillo after the application of the didactic and technological tool.

Null Hypothesis ( $\mathrm{HO})$ : A didactic and technological tool, it has no effect on the level of satisfaction of the Systems Engineering students at the National University of Trujillo, in the 2020-II semester. $\mathrm{HO}: \mu \mathrm{B}-\mu \mathrm{A} \leq 0$

Alternative Hypothesis $(\mathrm{Ha})$ : A didactic and technological tool increases the level of satisfaction of the Systems Engineering students at the National University of Trujillo, in the 2020-II semester. Ha: $\mu \mathrm{B}-\mu \mathrm{A}>0$

Result of the statistical hypothesis test

$\mathrm{t} \alpha=0.05=12.71$

tc $=-3.3675 \mathrm{E}+01$

Given that: $12.71>-3.3675 \mathrm{E}+01$; the null hypothesis $\mathrm{H} 0$ must be rejected: $\mu \mathrm{B}-\mu \mathrm{A} \leq 0$; and therefore, the alternative hypothesis Ha must be accepted: $\mu \mathrm{B}-\mu \mathrm{A}>0$.

It is concluded then that a didactic and technological tool increases the level of satisfaction of the Systems Engineering students at the National University of Trujillo, in the 2020-II semester.

Analysis and discussion of results

a) Qualitative Indicator: "Level of motivation for the study"

Table 5. Impact on the motivation level for the study

\begin{tabular}{ccccccc}
\hline Indicator & \multicolumn{2}{c}{$\begin{array}{c}\text { Average score with the } \\
\text { current system }\end{array}$} & \multicolumn{2}{c}{$\begin{array}{c}\text { Average score with the } \\
\text { new system }\end{array}$} & \multicolumn{2}{c}{ Impact level } \\
& Points & $\%$ & Points & $\%$ & Points & $\%$ \\
\hline $\begin{array}{c}\text { Motivation level } \\
\text { for the study }\end{array}$ & 3.03 & $100 \%$ & 3.27 & $108 \%$ & 0.24 & $8 \%$ \\
\hline
\end{tabular}

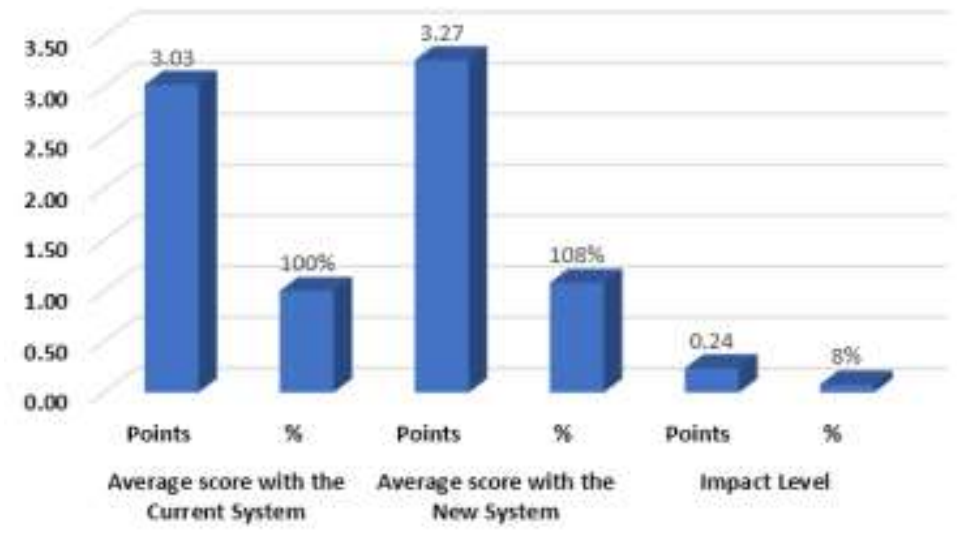

Figure 1: Level of motivation for the study 


\section{Journal of Sciences and Engineering}

Vol. 5, $\mathrm{N}^{\circ} 2,2021$

Copyright @ 2021, CINCADER.

ISSN 2523-9503

DOI: https://doi.org/10.32829/sej.v5i2.143

\section{CINCADER}

Centre of Research and Training for

Regional Development

Online at www.journals.cincader.org

Interpretation:

The level of motivation for the study with the current system is 3.03 , in this case, the level of appreciation is "Neither satisfactory nor unsatisfactory"; When applying the didactic and technological tool, the result was: 3.27, whose assessment is also, "Neither satisfactory, nor unsatisfactory". There is a slight motivation for the study since the values were modified from the value 3.03 to the value 3.27 .

Qualitative indicator: Level of perception of the educational service

Table 6. Perception level of the educational service

\begin{tabular}{|c|c|c|c|c|c|}
\hline \multirow[t]{2}{*}{ Indicator } & \multicolumn{2}{|c|}{$\begin{array}{l}\text { Average score with the } \\
\text { current system }\end{array}$} & \multirow{2}{*}{$\begin{array}{l}\text { Average score with the } \\
\text { new system } \\
\text { Points }\end{array}$} & \multicolumn{2}{|c|}{ Impact level } \\
\hline & Points & $\%$ & & Points & $\%$ \\
\hline $\begin{array}{l}\text { Perception level } \\
\text { for the study }\end{array}$ & 2.63 & $100 \%$ & $124 \%$ & 0.64 & $24 \%$ \\
\hline
\end{tabular}

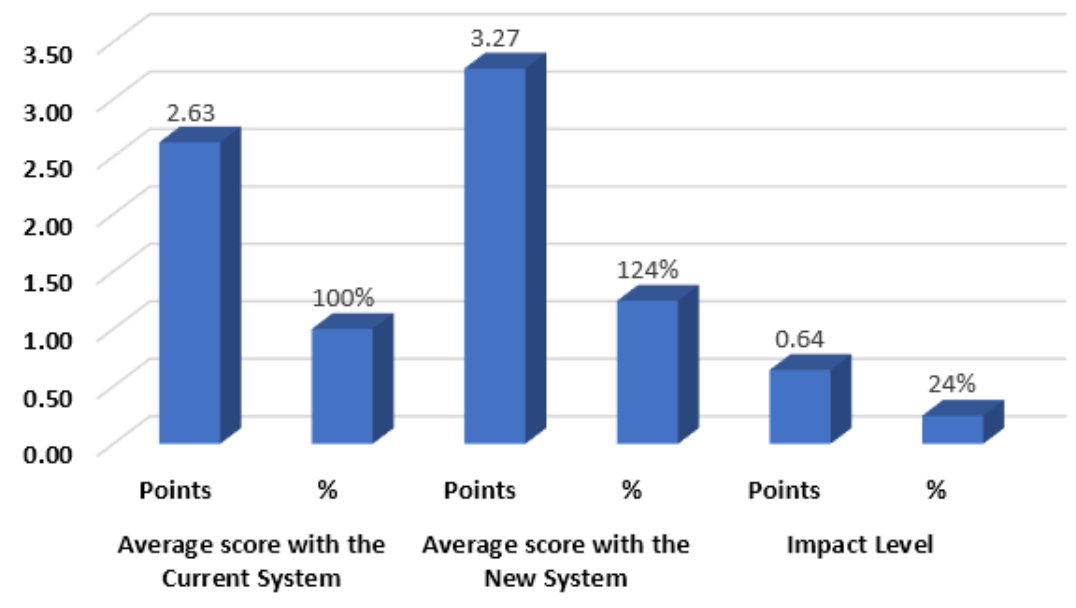

Figure 2: Perception level of the educational service

Interpretation:

The level of perception of educational services by Systems Engineering students at the National University of Trujillo, with the current system was 2.63, which means that it is; "Neither Satisfactory, nor Unsatisfactory"; When using the didactic and technological tool, the result was 3.27 , which is equivalent to "Neither Satisfactory, nor Unsatisfactory".

Qualitative indicator: Level of student satisfaction

Table 7. Level of student satisfaction

\begin{tabular}{|c|c|c|c|c|c|c|}
\hline \multirow[t]{2}{*}{ Indicator } & \multicolumn{2}{|c|}{$\begin{array}{l}\text { Average score with the } \\
\text { current system }\end{array}$} & \multirow{2}{*}{\multicolumn{2}{|c|}{$\begin{array}{c}\text { Average score with the } \\
\text { new system } \\
\text { Points }\end{array}$}} & \multicolumn{2}{|c|}{ Impact level } \\
\hline & Points & $\%$ & & & Points & $\%$ \\
\hline $\begin{array}{l}\text { Level of student } \\
\text { satisfaction }\end{array}$ & 2.80 & $100 \%$ & 3.29 & $117 \%$ & 0.48 & $17 \%$ \\
\hline
\end{tabular}




\section{Journal of Sciences and Engineering}

Vol. 5, $\mathrm{N}^{\circ} 2,2021$

Copyright @ 2021, CINCADER.

ISSN 2523-9503

DOI: https://doi.org/10.32829/sej.v5i2.143

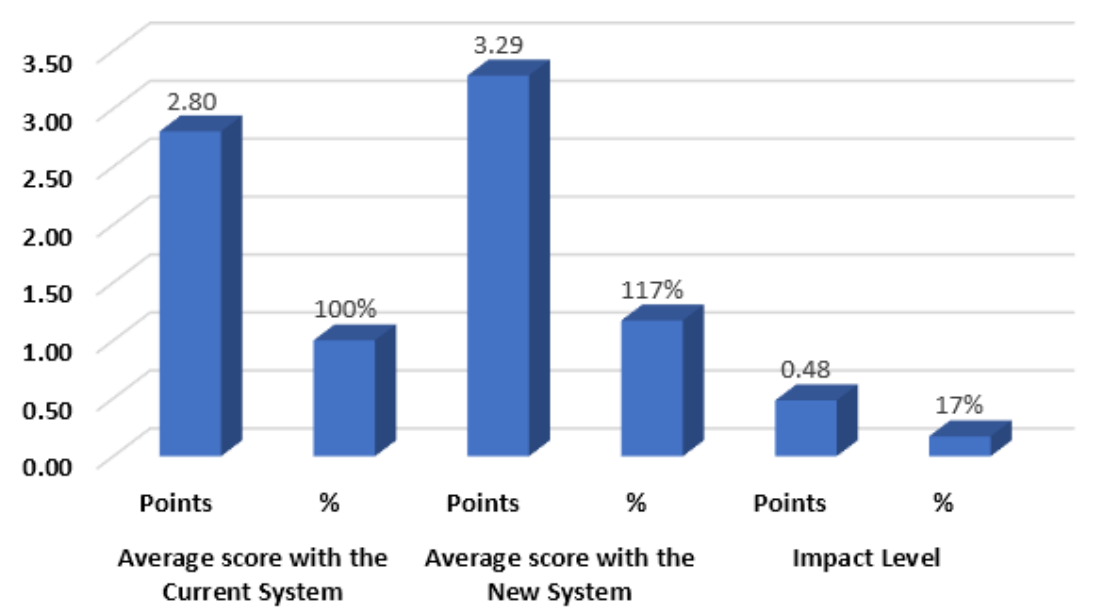

Figure 3: Student Satisfaction Level

Interpretation:

The level of satisfaction of the Systems Engineering students at the National University of Trujillo, with the current system is 2.80; that is to say; "Neither Satisfactory, nor Unsatisfactory"; When using the didactic and technological tool, this value rose to 3.29; which is equivalent to "Neither Satisfactory, nor Unsatisfactory"

\section{Conclusions}

The level of motivation for study in Systems Engineering students presents an impact of change with an increase in the level of motivation of $8 \%$ (See table 5). What's more; when doing the statistical test with t-student distribution, based on the sample size of the indicator: Level of motivation for the study; It can be seen that the results evaluated in the control group before the use of the didactic and technological tool were lower than the results evaluated in the research group after the use of didactic and technological tools; Therefore, it is concluded that if there is an increase in the level of motivation for the study as a consequence of an influence on the use of these tools by the student population of the Systems Engineering career of the 2020-II semester.

The level of perception of educational services by Systems Engineering students at the National University of Trujillo, had an increase in the impact of the change of the order of $24 \%$ (See table 6). In addition; When doing the statistical test with t-student distribution, it can be seen that the results evaluated in the control group before the use of the didactic and technological tool were lower than the results evaluated in the research group after the use of this tool; Therefore, it is concluded that if there is an increase in the level of perception of educational services as a result of an influence on the use of didactic and technological tools by the student population of the Systems Engineering career for the 2020 semester -II.

The level of satisfaction of the Systems Engineering students at the National University of Trujillo, had an increase in the impact of the change in the order of $17 \%$ (See table 7 ). In addition; When doing the statistical test with t-student distribution, it can be seen that the results evaluated in the control group before the use of the didactic and technological tool were lower than the results evaluated in the research group after the use of this tool; Therefore, it is concluded that if there is an increase in the level of student satisfaction as a result of an influence on the use of didactic and technological tools by the student population of the Systems Engineering career for the 2020 semester- II. 


\section{Journal of Sciences and \\ Engineering}

Vol. 5, $\mathrm{N}^{\circ} 2,2021$

Copyright (c) 2021, CINCADER.

ISSN 2523-9503

DOI: https://doi.org/10.32829/sej.v5i2.143

Finally, according to the analysis of the values obtained regarding the incentive indicators for the study (Level of motivation for the study, level of perception of educational services and level of student satisfaction); It is appreciated that there is a favorable improvement in the incentive for study with the application of the didactic and technological tool, during the 2020-II semester.

\section{Acknowledgments}

Our sincere thanks to the School of Professional Systems Engineering at the National University of Trujillo for facilitating access and the corresponding information and to the students for giving us their time in carrying out this research.

\section{References}

Camilo Díaz, J. M., \& Marín Useda, J. $\quad$ D. 2014. https://repository.ucatolica.edu.co/handle/10983/1380
Fierro Barriales,
A.
L. 2018. http://repositorio.ucv.edu.pe/bitstream/handle/UCV/21487/Fierro_BAL.pdf?sequence=1\&isAll owed=y

Gonzales Patiño, R., \& Moreno Valencia, A. Z. (09 de 2018). Interacciones educativas. http://vitela.javerianacali.edu.co/handle/11522/10758
More
Barrantes,
R.,
\& Velasco
Tapia,
A.
G. 2018. http://tesis.pucp.edu.pe/repositorio/handle/123456789/12897

Rodriguez Ramirez, P. C. 2016. http://tesis.pucp.edu.pe/repositorio/handle/123456789/7205

TIC para innovar. 2014. S/N. http://www.ticeducacionec.com/2014/05/30-plataformas-virtualeseducativas.html 